\title{
Automated water quality monitoring system development via LabVIEW for aquaculture industry (Tilapia) in Malaysia
}

\author{
Nor Azlan Othman, Nor Salwa Damanhuri, Mohamad Amirul Syafiq Mazalan, \\ Sarah Addayani Shamsuddin, Mohd Hussaini Abbas, Belinda Chong Chiew Meng \\ Faculty of Electrical Engineering, Universiti Teknologi MARA, Malaysia
}

\begin{tabular}{l}
\hline Article Info \\
\hline Article history: \\
Received Apr 15, 2020 \\
Revised Apr 13, 2020 \\
Accepted Apr 27, 2020
\end{tabular}

\section{Keywords:}

Aquaculture

Automated

Data acquisition

LabVIEW

Water quality

\begin{abstract}
Maintaining the quality of the water quality is one of the important aspects that play a substantial effect on the aquaculture industry especially in the tilapia industry. The quality of the water needs to be continuously monitored as any deviation from the allowed critical parameters such as water temperature and potential of hydrogen $(\mathrm{pH})$ can cause unwanted scenarios such as disease, stress, higher mortality rate and profit loss. Currently, the monitoring process adopted by most fish breeders is done manually by using a portable sensor. This approach is found to be very tedious, ineffective use of manpower and time consuming particularly for the large-scale aquaculture industry. Hence, this research focuses on developing a simple, low-cost automated water quality monitoring system for the tilapia industry via LabVIEW software. The developed system will be able to monitor the parameter in real-time continuously with the capability of record and analyze each reading in a more efficient way. A data acquisition (DAQ) of NI myRIO-1900 is used as an interface between sensors and a monitoring station equipped with LabVIEW. Additionally, the developed system is equipped with an alarm system to alert the user when any deviation of the parameters occurs. Result shows that the system has a small range of average relative error of $4.28 \%$ and $6.22 \%$ for temperature and $\mathrm{pH}$ level respectively as compare to the portable sensor. Note that the errors are down to the selection of sensors. Furthermore, the developed prototype of the monitoring system has advantages in terms of its flexibility in extending the system with more sensors and allows a longer period of data collection without human intervention. The system is also upgradable with the integration of a control element to control the parameter when the monitored parameter is exceeded the threshold value. Succinctly, the system offers lots of advantages to the aquaculture industries with further improvement leads to better performance.
\end{abstract}

Copyright $(0) 2020$ Institute of Advanced Engineering and Science. All rights reserved.

Corresponding Author:

Nor Salwa Damanhuri,

Faculty of Electrical Engineering,

Universiti Teknologi MARA, Cawangan Pulau Pinang,

13500 Permatang Pauh, Pulau Pinang, Malaysia.

Email: norsalwa071@uitm.edu.my

\section{INTRODUCTION}

Malaysia has been recognized as a top 15 of global producers of aquaculture production [1]. Moreover, aquaculture industries in Malaysia play a significant role in the Malaysian national economy by supplying domestic and foreign demands of cheap protein food and by providing employment to the population [2, 3]. In ensuring the effectiveness and good profit return from this aquaculture industry, water quality has played a major factor particularly in the breeding process $[4,5]$. The quality needs to be continuously monitored as any deviation from the allowed parameter/ measurement range can cause the unwanted scenario such as disease, stress, death and profit loss [6-9]. Different types of fish have a specific 
range of water quality level aspects such as temperature, potential of hydrogen $(\mathrm{pH})$ level, dissolved oxygen (DO) concentration and other parameters. Maintaining a good quality of water is crucial for the fish industry particularly in the tilapia industry [10]. Prior studies show that the water quality can be achieved through microbial measurements as well as physiochemical measurements [11, 12]. Hypothetically, the amount of oxygen dissolved in water can be highly affected by the temperature of the water itself. Thus, critical parameters such as $\mathrm{pH}$ level and temperature of the water need to be monitored continuously to ensure the production of healthy fish.

Currently, in most of the aquaculture industries in Malaysia, the monitoring process of the quality of the water is carried out manually by using a portable sensor [13, 14]. Previously, the monitoring activity need to be done manually at the site and record it in a logbook [14]. Only trained and qualified personel can conduct the test and take measurements of water quality parameters [15]. This approach is found to be very tedious and time consuming (overall process to read and record the measurement will take almost half a day). Additionally, for a large-scale industry, this approach is very impractical with inefficient use of time management and manpower.

In order to improve the conventional method of monitoring process, an automated monitoring system is thought to be the best approach to cater those stated issues. Countries such as China, Taiwan and India have developed systems using sophisticated technologies to monitor the quality of the water [15, 16]. Different kind of topology has been adopted by many studies to develop an automated monitoring system [17-23].

Thus, this research aims to design and develop a low-cost automated water quality monitoring system specifically for the tilapia industry that able to perform the monitoring and recording of the water quality parameters automatically. The implementation of the developed system will help the industry to maximize the operation in terms of manpower and time management. The developed system will be able to not only monitor the parameter on-line (continuously), but also capable of recording and analysing each reading in a more efficient way

\section{RESEARCH METHOD}

The development of the monitoring system is divided into two section; system and hardware development.

\subsection{System development}

Water quality determines how well fish grow and whether or not to survive. Temperature and $\mathrm{pH}$ level have been chosen to be monitored in this system. These two parameters tend to change quickly and it can effect to the system if allowed to operate out-of-range [24]. Figure 1 depicts a block diagram of this system. Each tank is equipped with 2 sensors which measure the temperature and $\mathrm{pH}$ level of the water. These sensors are connected to a data acquisition system (DAQ), NI myRIO-1900 that is used as an interface to communicate between monitoring workstation (equipped with LabVIEW program) and sensors. With a built-in wi-fi feature in MyRIO, data received from sensors will be transferred to the monitoring workstation through a wi-fi connection. Figure 2 shows the layout of the overall system.

The developed system consists of two sensors (temperature and $\mathrm{pH}$ sensor) and DAQ NI myRIO1900 from National Instrument. The NI myRIO-1900 offers a compact embedded device with analog input (AI), analog output (AO), digital input and output (DIO), audio, and energy output. The NI myRIO-1900 is connected via USB and 802.11b.g.n to a host.

LabVIEW software is used to program the system in order to allow the system to detect the signal and execute the task of monitoring by using the sensors that have been set up. Figure 3 shows the LabVIEW front panel for the system. LabVIEW can be understood easily and utilized by the user [6, 25]. The signal comes from each type of sensor are shown and displayed through this front panel. Figure 4 illustrates the LabVIEW block diagram panel. Standard range for water quality parameter set by fisheries research institute (FRI) Malaysia as shown in Table 1.

The minimum and maximum value of temperature and $\mathrm{pH}$ level are set based on the requirement from Fisheries Research Institute (FRI) Malaysia. The maximum value of the temperature is set to $32^{\circ} \mathrm{C}$. When the value reaches $32^{\circ} \mathrm{C}$ the indicator will turn red. The relationship between temperature and DAQ system is given as follow:

$$
\text { Temperature }\left({ }^{\circ} \mathrm{C}\right)=\text { Vout } x 100
$$

Additionally, the $\mathrm{pH}$ is set to be in the range of 6.5 to 8.5 (based on standard range provided by Fisheries Research Institute (FRI) Malaysia). As the value of the $\mathrm{pH}$ reaches lower than 6.5 the indicator will turn into red colour. 


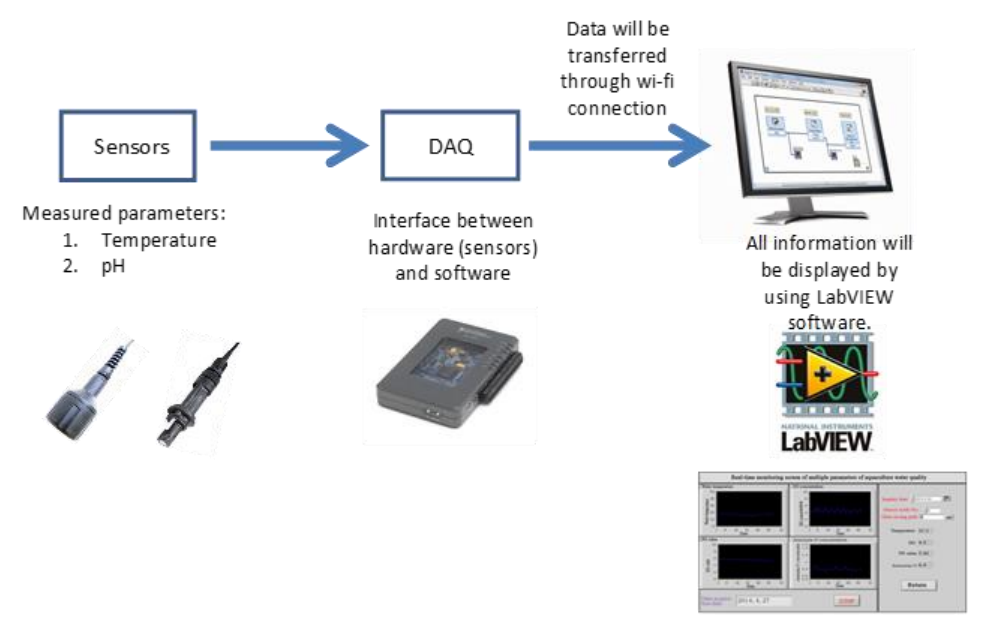

Figure 1. The block diagram of water quality monitoring system for the tilapia industry

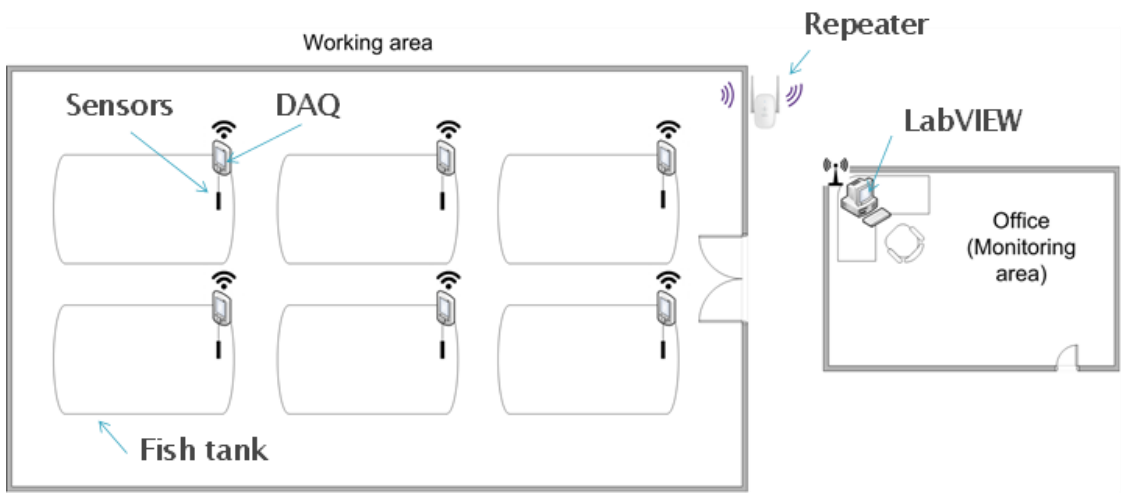

Figure 2. The layout water quality monitoring system for the tilapia industry

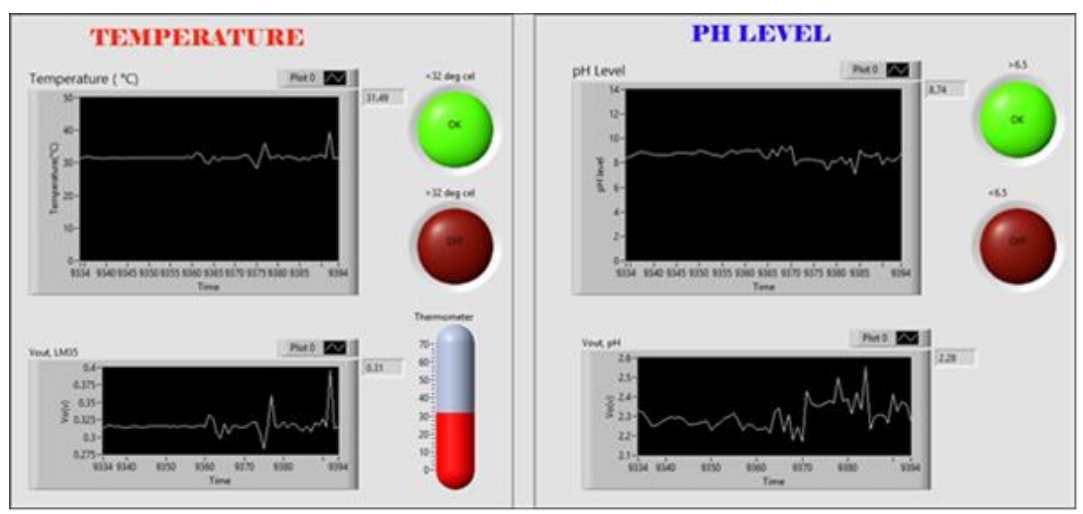

Figure 3. The front panel of the system via LabVIEW software

Table 1. Standard range for water quality parameter set by fisheries research institute (FRI) Malaysia

\begin{tabular}{ccc}
\hline Parameter & Standard Ranges & Unit \\
\hline Temperature & $28-32$ & ${ }^{\circ} \mathrm{C}$ \\
DO & $>4$ & $\mathrm{ppm}$ \\
pH & $6.5-8.5$ & \\
Salinity & $24-32$ & $\mathrm{ppt}$ \\
Ammonia (NH3-N) & $0.1-0.5$ & $\mathrm{ppm}$ \\
Nitrate (NO3) & $0-10$ & $\mathrm{ppm}$ \\
Nitrite (NO2) & $<0.3$ & $\mathrm{ppm}$ \\
\hline
\end{tabular}




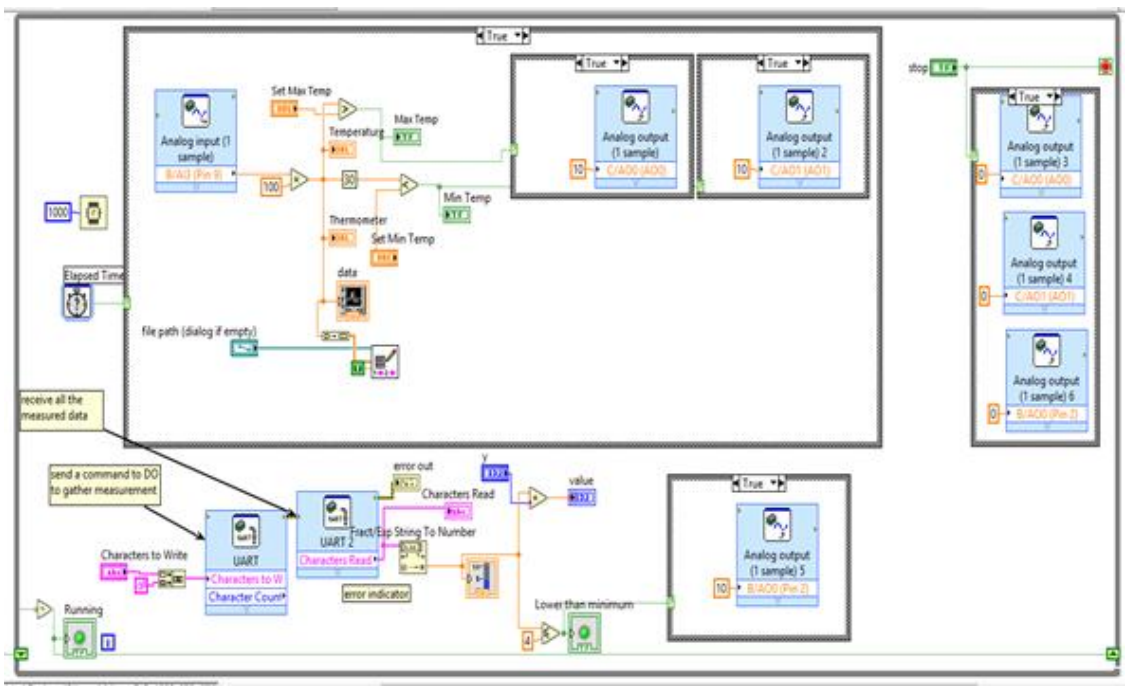

Figure 4. The block diagram of the system via LabVIEW software

\subsection{Hardware development}

The hardware development stage involves the circuit of $\mathrm{pH}$ that acts as signal conditioning. Figure 5 shows the connection of sensors, signal conditioning and data acquisition system. The modified temperature sensor, LM35 is directly connected to the analog input pin 9 on connector B of NI myRIO-1900 while the pH sensor is connected to $\mathrm{pH}$ probe $\mathrm{BNC}$ connector. The $\mathrm{pH}$ output terminal from the $\mathrm{pH}$ circuit is connected to analog input pin 5 connector A of NI myRIO.

LM35 is used as a temperature sensor while the $\mathrm{pH}$ sensor is the atlas scientific sensor. The $\mathrm{pH}$ circuit acts as signal conditioning while the NI myRIO-1900 device as data acquisition system and LabVIEW software as a monitoring system. The two sensors are constantly submersed into the water. Data gathered from sensors will pass through DAQ (NI myRIO-1900) system before being displayed and analysed in the LabVIEW. The data collected are being monitored through a monitoring station consists of LabVIEW programming. Figure 6 illustrate the experimental setup for automated monitoring system. Figure 7 shows the conventional set-up (manual process) versus the developed automated set-up.

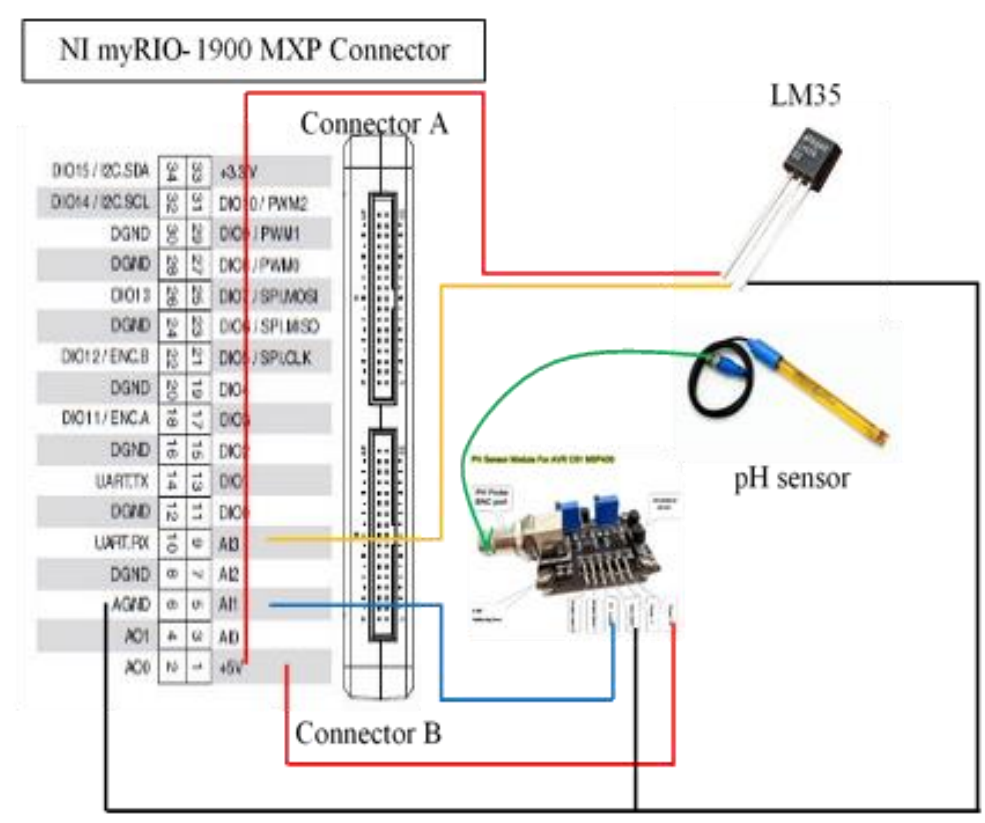

Figure 5. The hardware connection setup 


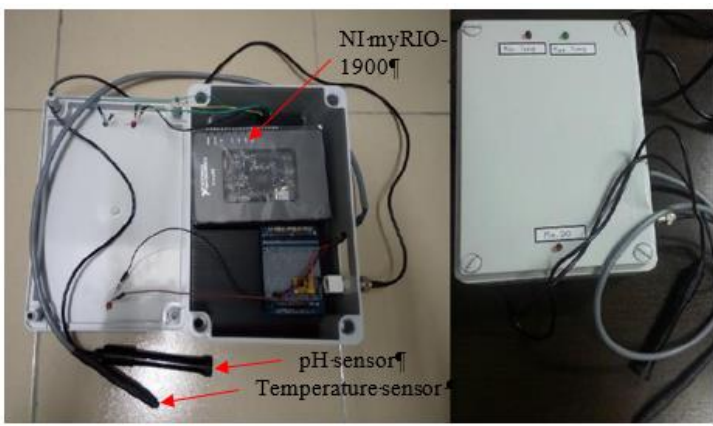

Figure 6. Experimental setup for automated monitoring system
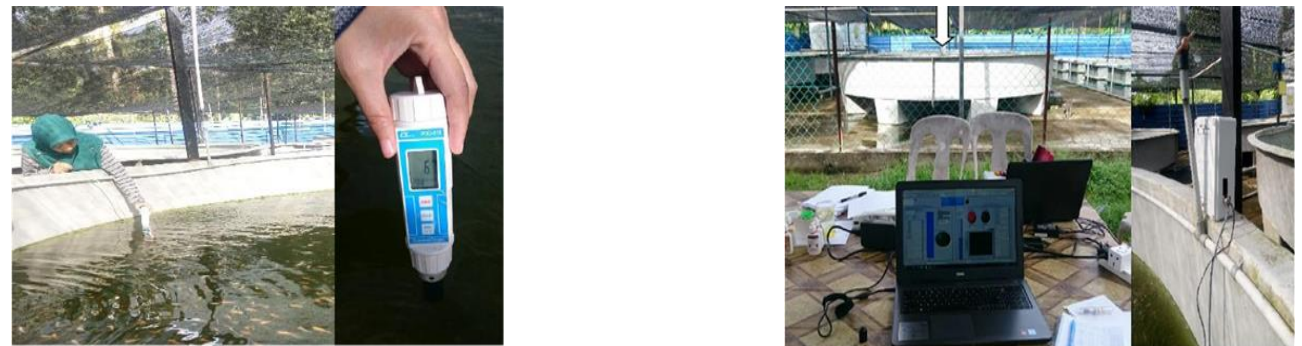

Figure 7. Manual set-up versus automated set-up

\subsection{Data analysis}

Two different set-ups have been deployed at the fish tank; manual system and automated system. Both systems are running simultaneously although the manual system takes longer time in gathering the data. The temperature and $\mathrm{pH}$ values are continuously gathered from the fish tank. Further analysis in determining the accuracy of the automated system is performed by calculating the percentage of error are stated as follow:

$$
\% \text { error }=\left|\frac{\text { Value }_{\text {automated }}-\text { Value }_{\text {manual }}}{\text { Value }_{\text {manual }}}\right| \times 100
$$

\section{RESULTS AND ANALYSIS}

Figure 8 shows the front panel of temperature when the temperature of of water exceeds $32^{\circ} \mathrm{C}$ based on the system setup. By using the formula in (1), the temperature value during that time is $32^{\circ} \mathrm{C}$. Hence, the LED will turn into red colour as an alarm indicator to alert the user that the temperature has arise.

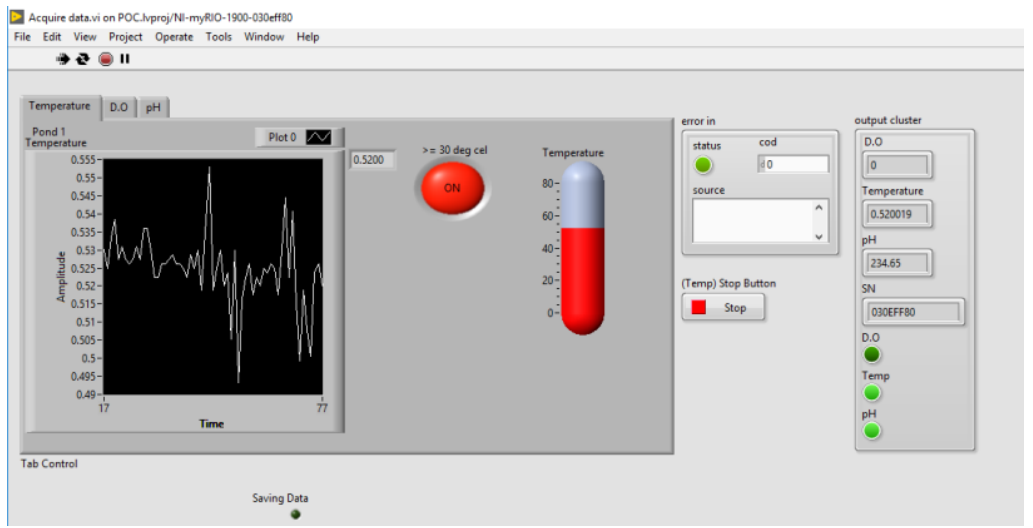

Figure 8. The front panel shows when the temperature exceeds $32^{\circ} \mathrm{C}$. 
Table 2 tabulates the accuracy of automated system by comparing the data gathered between these two set-ups (manual versus automated set-up). It shows that the percentage error between manual and automated measurements are less than $7 \%$ for the temperature parameter. These measurements proved that the developed automated system is able to measure correctly on those required parameters. Hence, it is proven that automated monitoring and data collection is suitable to be developed for thisaquaculture industries.

Table 2. The accuracy of temperature sensor of the system

\begin{tabular}{cccc}
\hline No of data taken & Automated set-up $\left({ }^{\circ} \mathrm{C}\right)$ & Manual set-up $\left({ }^{\circ} \mathrm{C}\right)$ & Percentage of error $(\%)$ \\
\hline 1st & 49.56 & 49.50 & 0.12 \\
2nd & 47.36 & 45.30 & 4.55 \\
3rd & 41.26 & 39.80 & 3.67 \\
4th & 36.50 & 34.20 & 6.73 \\
5th & 32.23 & 30.60 & 5.33 \\
6th & 29.17 & 27.70 & 5.31 \\
\hline
\end{tabular}

The data of temperature and $\mathrm{pH}$ level of the water in tilapia tank were measured and collected. The readings of temperature and $\mathrm{pH}$ level of the natural water sample were taken for around 2 days. The reading was taken every 10 minutes for each parameter. Table 3 tabulates the readings of temperature and $\mathrm{pH}$ level. From the table, the relationship between the temperature and $\mathrm{pH}$ level can be seen. On 28 May 2019 at $6 \mathrm{pm}$, the value of $\mathrm{pH}$ level is 6.242 when the temperature at $31.738^{\circ} \mathrm{C}$. This shows that at the highest temperature, the $\mathrm{pH}$ level is lower [19]. While on 28 May 2019 at $11.20 \mathrm{am}$, the value of the pH level is 6.702 when the temperature at $31^{\circ} \mathrm{C}$. This shows that the lower temperature produces a higher value of $\mathrm{pH}$ level. Unfortunately, this condition can be seen on the first day only because the properties of the water sample start to change to acidic on the second day. This is because the value of temperature does not affect the properties of the water sample. Thus, on the first day, it can be concluded that the higher the temperature produces a lower $\mathrm{pH}$ level and vice versa. With this automated measurement, this system is able to guide and alert the user on the water quality of the tilapia industry.

Table 3. Table of temperature and $\mathrm{pH}$ level with time

\begin{tabular}{ccc}
\hline Date/Time & Temperature $\left({ }^{\circ} \mathrm{C}\right)$ & $\mathrm{pH}$ level \\
\hline 28/5/2019 8:00 & 31.86 & 6.47 \\
28/5/2019 11:20 & 31.01 & 6.70 \\
28/5/2019 14:40 & 31.74 & 6.29 \\
28/5/2019 18:00 & 31.74 & 6.24 \\
28/5/2019 21:20 & 31.74 & 6.34 \\
29/5/2019 0:40 & 31.74 & 6.31 \\
29/5/2019 4:00 & 31.62 & 6.63 \\
29/5/2019 7:20 & 31.37 & 6.49 \\
29/5/2019 10:40 & 30.52 & 6.39 \\
$29 / 5 / 201914: 00$ & 30.27 & 6.38 \\
$29 / 5 / 201917: 20$ & 29.91 & 6.29 \\
$29 / 5 / 201920: 40$ & 30.52 & 6.37 \\
\hline
\end{tabular}

\section{CONCLUSION}

As a conclusion, this research is able to measure the water quality for tilapia industry based on two parameters, which are temperature and $\mathrm{pH}$ value. The system delivered a promising result with a significantly small percentage of error of less than $7 \%$ between automated and manual systems. In addition, this automated system is capable of constantly monitoring the water quality parameters within the desirable range suitable for aquaculture industry. The fish breeder will be alerted at the right time when the parameters go beyond the specified range. Thus, this shows that this low-cost system is able to deliver an accurate result that helps the fish breeder in monitoring the water quality automatically. For recommendation, this system can be improved by adding other parameters such as dissolved oxygen, turbudity and other parameters.

\section{ACKNOWLEDGEMENTS}

Universiti Teknologi MARA Cawangan Pulau Pinang and Ministry of Education Malaysia for providing research funding via Public- Private Research Network grant. Pn. Anita Ahmad, Managing Director of Aquatech Bio Resources Sdn. Bhd for giving the permission to undergo the test. 


\section{REFERENCES}

[1] S. Fathi, A. N. Harun, S. Rambat, and N. A. Tukiran, "Current Issues in Aquaculture: Lessons from Malaysia," Advanced Science Letters, vol. 24, pp. 503-505, 2018.

[2] I. W. Witus and L. W. Vun, "Aquaculture in Malaysia: a short review on current policy and legislation," Transactions on Science and Technology, vol. 3, no. 1-2, pp. 150-154, 2016.

[3] M. Othman, M. Hashim, M. Yeo, M. Azmai, N. Iksan, G. Ho, and Z. Merican, "Transforming the Aquaculture Industry in Malaysia," World Aquaculture Society, pp. 15-23, 2017.

[4] C. E. Boyd and C. S. Tucker, "Pond aquaculture water quality management," Springer Science \& Business Media, 2012.

[5] C. E. Boyd and C. S. Tucker, "Handbook for aquaculture water quality," Handbook for Aquaculture Water Quality, pp. 439, 2014.

[6] V. K. Beena and K. Moinuddin, "Water Quality Measurement and Control from Remote Station for pisiculture using NI myRIO," International journal for research in Electronic and Telecommunication, vol. 2, no. 4, pp. 16-21, 2015.

[7] A. Abdulrazaq, D. Mustapha, A. Ismail, M. Momoh, S. Abdulhamid, J. Obari, and M. Saliu, "LabVIEW Interfaced PC-Based Fishpond Monitoring System," ATBU Journal of Science, Technology and Education, vol. 6, no. 2, pp. 217-225, 2018.

[8] N. A. J. Salih, I. J. Hasan, and N. I. Abdulkhaleq, "Design and implementation of a smart monitoring system for water quality of fish farms," Indonesian Journal of Electrical Engineering and Computer Science, vol. 14, no. 1, pp. 44-50, 2019.

[9] J. S. Diana, J. P. Szyper, T. R. Batterson, C. E. Boyd, and R. H. Piedrahita, "Water quality in ponds," Dynamics of pond aquaculture, pp. 53-72, 1997.

[10] N. Ezeanya, G. Chukwuma, K. Nwaigwe, and C. Egwuonwu, "Standard Water Quality Requirements and Management Strategies for Fish Farming (A Case Study of Otamiri River)," International Journal of Research in Engineering and Technology, vol. 4, no. 3, pp. 1-5, 2015.

[11] N. A. Cloete, R. Malekian, and L. Nair, "Design of smart sensors for real-time water quality monitoring," IEEE access, vol. 4, pp. 3975-3990, 2016.

[12] M. Bilal, A. Gani, M. Marjani, and N. Malik, "A Study on Detection and Monitoring of Water Quality and Flow," in 2018 12th International Conference on Mathematics, Actuarial Science, Computer Science and Statistics (MACS), pp. 1-6. 2018.

[13] S. Sridharan, "Water Quality Monitoring System Using Zigbee Based Wireless Sensor Network," International Journal of Engineering \& Technology, vol. 9, no. 10, pp. 24-28, 2014.

[14] C. Z. Myint, L. Gopal, and Y. L. Aung, "Reconfigurable smart water quality monitoring system in IoT environment," in 2017 IEEE/ACIS 16th International Conference on Computer and Information Science (ICIS), pp. 435-440, 2017.

[15] A. Doni, C. Murthy, and M. Kurian, "Survey on multi sensor-based air and water quality monitoring using IoT," Indian J. Sci. Res, vol. 17, no. 2, pp. 147-153, 2018.

[16] K. S. Adu-Manu, C. Tapparello, W. Heinzelman, F. A. Katsriku, and J.-D. Abdulai, "Water quality monitoring using wireless sensor networks: Current trends and future research directions," ACM Transactions on Sensor Networks (TOSN), vol. 13, no. 1, pp. 1-41, 2017.

[17] L. Hongpin, L. Guanglin, P. Weifeng, S. Jie, and B. Qiuwei, "Real-time remote monitoring system for aquaculture water quality," International Journal of Agricultural and Biological Engineering, vol. 8, no. 6, pp. 136-143, 2015.

[18] T. Le Dinh, W. Hu, P. Sikka, P. Corke, L. Overs, and S. Brosnan, "Design and deployment of a remote robust sensor network: Experiences from an outdoor water quality monitoring network," in 32nd IEEE Conference on Local Computer Networks (LCN 2007), pp. 799-806, 2007.

[19] D. S. Simbeye and S. F. Yang, "Water quality monitoring and control for aquaculture based on wireless sensor networks," Journal of networks, vol. 9, no. 4, pp. 840, 2014.

[20] O. Postolache, J. D. Pereira, and P. S. Girão, "Wireless sensor network-based solution for environmental monitoring: Water quality assessment case study," IET Science, Measurement \& Technology, vol. 8, no. 6, pp. 610-616, 2014.

[21] F. Saparudin, T. Chee, A. Ab Ghafar, H. Majid, and N. Katiran, "Wireless water quality monitoring system for high density aquaculture application," Indonesian Journal of Electrical Engineering and Computer Science, vol. 13, no. 2, pp. 507-513, 2019.

[22] M. A. Ab Aziz, M. Abas, M. K. A. A. Bashri, N. M. Saad, and M. Ariff, "Evaluating IoT based passive water catchment monitoring system data acquisition and analysis," Bulletin of Electrical Engineering and Informatics, vol. 8, no. 4, pp. 1373-1382, 2019.

[23] H. Khaleeq, A. Abou-ElNour, and M. Tarique, "A Reliable Wireless System for Water Quality Monitoring and Level Control," Network Protocols \& Algorithms, vol. 8, no. 3, pp. 1-14, 2016.

[24] P. Fowler, D. Baird, R. Bucklin, S. Yerlan, C. Watson, and F. Chapman, Microcontrollers in recirculating aquaculture systems, University of Florida, EES-326, 1994.

[25] N. T. K. Duy, T. T. Hieu, and L. H. D. Khanh, "A versatile, low poweron monitoring and control system for shrimp farms based on NI myRIOand ZigBee network," in 2015 International Conference on Computation of Power, Energy, Information and Communication (ICCPEIC), pp. 0282-0287. 2015 


\section{BIOGRAPHIES OF AUTHORS}
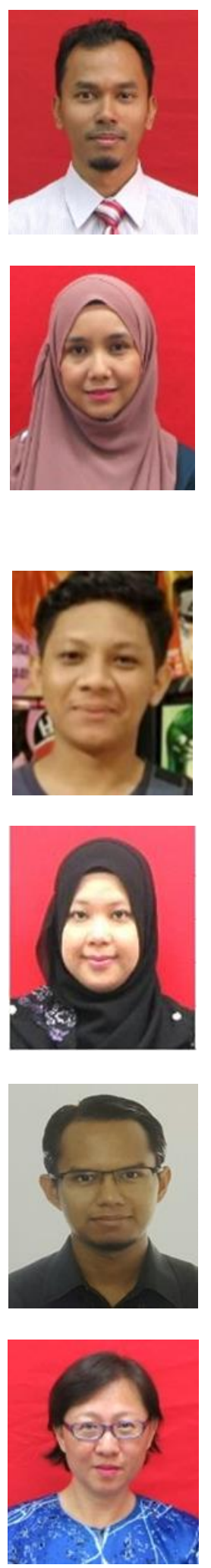

Nor Azlan Othman received her B.Sc. (Hons) in Electrical \& Electronics Engineering from Universiti Tenaga Nasional (UNITEN) Malaysia. In 2004, he received the Excellence Scheme Programme from MARA to pursue his MSc. in Control Systems Engineering in University of Sheffield, United Kingdom. He had several years of experiences as a R\&D Engineer in Sony and Motorola Malaysia. He obtained his $\mathrm{PhD}$ in Bioengineering from University of Canterbury, New Zealand in 2015. Currently, he is a senior lecturer in Faculty of Electrical Engineering, UiTM Pulau Pinang. His research interests include physiological modelling, parameter identification, insulin sensitivity for type 2 diabetes, renewable energy and control systems.

Nor Salwa Damanhuri received her B.Sc. (Hons) in Electrical \& Electronics Engineering from Universiti Tenaga Nasional (UNITEN) Malaysia. In 2004, she received the Excellence Scheme Programme from MARA to pursue her MSc. in Control Systems Engineering in University of Sheffield, United Kingdom. She had 4 years experiences as a Product Engineer in Freescale Semiconductor Malaysia (fka Motorola Semiconductor) before embarking her journey as a lecturer at the Universiti Teknologi MARA (UiTM) Pulau Pinang. She obtained her PhD in Bioengineering from University of Canterbury, New Zealand in 2015. Currently, she is a senior lecturer in Faculty of Electrical Engineering, UiTM Pulau Pinang. Her research interests include lung mechanics, system identification methods, modelling for type 2 diabetic patients and solar PV system.

Mohamad Amirul Syafiq Mazalan received his Bachelor Degree in Electrical \& Electronics Engineering from Universiti Teknologi MARA (UiTM) Cawangan Pulau Pinang. At present, he is an engineer in one of the multinational companies in Penang.

Sarah Addyani Shamsuddin obtained her Diploma in Electrical Engineering (Instrumentation) from Universiti Teknologi MARA (UiTM) Pulau Pinang in 2008. She continued her B.Eng (Hons) of Electrical Engineering at Universiti Teknologi MARA (UiTM) Shah Alam and graduated in 2011. She furthered her MSc Electrical Engineering also at Universiti Teknologi MARA (UiTM) Shah Alam in 2014. Her research interests include applications of sensors, optical sensing and modelling for type 2 diabetic patients. She has teaching experience in school and currently at UiTM Pulau Pinang. As for the industrial experiences, she managed to gain those exposures from a multi discipline consultation company, Mecip (M) Sdn. Bhd.

Mohd Hussaini Abbas obtained his Diploma in Electronic (Communication) Engineering from Politeknik Sultan Haji Ahmad Shah (POLISAS) in 2003 and B.Eng Hons in Electrical (Electronics) Engineering from Universiti Teknologi MARA (UiTM) Shah Alam in 2007. He started his carrier as an academician at Kolej Poly-tech MARA (KPTM) Kuantan for about two years. Then he completes his MSc in Electronic System Design Engineering at Universiti Sains Malaysia (USM) in 2011. Currently, he is working as senior lecturer in Faculty of Electrical Engineering, Universiti Teknologi MARA (UiTM) Cawangan Pulau Pinang.

Dr. Belinda Chong Chiew Meng received her B.Sc. (Hons) and M. Eng. in Electrical Engineering in 1997 and 2002 from Universiti Teknologi Malaysia. She received the Ph. D degrees in 2017 from Universiti Sains Malaysia. Currently, she is a senior lecturer at the Faculty of Electrical Engineering, Universiti Teknologi MARA (UiTM), Cawangan Pulau Pinang, Malaysia. Her main research interests include image processing and intelligent system. 